\title{
UPAYA MENINGKATKAN AKTIVITAS DAN PRESTASI BELAJAR SISWA DALAM PEMBELAJARAN GEOMETRI MELALUI PENERAPAN MODEL PEMBELAJARAN REALISTIC MATHEMATIC EDUACTION
}

\author{
I Nyoman Darma \& I Wayan Suandhi \\ Program Studi Pendidikan Matematika, Fakultas Keguruan dan Ilmu Pendidikan, \\ Universitas Mahasaraswati Denpasar
}

\begin{abstract}
The learning model of realistics mathematics education (RME), which refers to social constructivism, providing opportunities for learners to explore and develop ideas. For the reason, the classroom action research was conducted with the aim to increase the learning activity and student achievement in learning geometry through the application of RME learning model in 5 grades of elementary students. It has been conducted through three cycles, and each cycle consists of three face-to-face activities in the classroom. Data on activity were collected by observation technique using a sheet of observation, while data of learning achievement were collected by testing learning outcomes. The results showed, from precycle the cycle I, the cycle I to II, and from II to III cycles, the tendency of increasing the students values in learning activities $(21.56 \%, 18.76 \%$ and $17.24 \%$ ), absorptive ability $(217.25 \%, 9,54 \%$, and $4.68 \%$ ), and mastery learning (not defined, $24.09 \%$ and $38.46 \%$ ). Thus, RME in geometry has increased, both activity and student learning achievement.
\end{abstract}

Key words: class action research, geometry, realistics mathematics education, learning activities

\section{PENDAHULUAN}

Pada umumnya masalah pendidikan matematika selalu menjadi sorotan karena masih rendahnya prestasi belajar siswa pada bidang studi tersebut. Oleh karena itu, peningkatan mutu pendidikan matematika selalu menjadi topik menarik untuk didiskusikan. Berbagai upaya telah dilakukan, dan berbagai metode pembelajaran telah dicobakan, namum hasil yang diperoleh belum optimal sesuai yang diharapkan. Hal ini disebabkan karena masih banyaknya anggapan siswa yang kurang positif terhadap matematika. Ada yang menganggap bahwa matematika sulit dipelajari, bahkan ada siswa merasa tegang kalau tiba waktunya untuk belajar matematika di sekolah. Banyak siswa yang menganggap bahwa matematika tidaklah lebih dari sekedar berhitung dan bermain dengan rumus dan angkaangka. Umumnya pelajaran matematika di sekolah menjadi momok bagi siswa. Di samping itu keluhan tentang kesulitan belajar matematika masih banyak dijumpai. Kesulitan belajar 
yang ditimbulkan tersebut tidak semata-mata hanya karena materi yang sulit, tetapi juga disebabkan oleh cara guru menyampaikan pelajaran yang sulit diterima oleh murid.

Untuk mangatasi masalah pembelajaran matematika di sekolah, khususnya di Sekolah Dasar (SD) berbagai pakar pendidikan matematika menyarankan agar siswa diarahkan mempelajari matematika dalam konteks dimana mereka dapat melihat penerapan matematika dalam situasi nyata. Jika dikaitkan dengan sifat matematika yang abstrak dan daya kognitif manusia yang bergerak dari konkret ke abstrak, maka akan lebih baik jika pada tingkat dasar matematika disajikan dalam bentuk konkret. Hal ini berarti bahwa pada tingkat pendidikan dasar matematika disajikan dengan mengaitkan hal-hal yang berada di sekeliling siswa. Oleh karena itu siswa akan merasa tidak asing dengan matematika dan sedikit demi sedikit mereka akan menyukai matematika. Selanjutnya diharapkan nantinya akan menghilangkan kesan bahwa matematika adalah momok bagi semua siswa.

Salah satu materi yang diajarkan di sekolah dasar adalah geometri. Pembelajaran geometri di sekolah dasar cenderung berorientasi pada guru. Dampak dari pembelajaran yang berorientasi pada guru adalah pembelajaran sering diinterpretasikan sebagai aktivitas utama yang dilakukan guru, yaitu guru mengenalkan materi, mungkin mengajukan satu atau dua pertanyaan, dan meminta siswa untuk menjawab pertanyaan tersebut. Jarang guru dalam pembelajarannya memulai dengan masalah nyata geometri yang kemudian diarahkan pada penemuan konsep geometri, prosedur matematika dan prinsip geometri. Akibat dari pembelajaran tersebut adalah siswa kurang mampu dalam penalaran geometri. Dengan demikian belajar matematika yang dimulai dari kehidupan nyata membuat pembelajaran menjadi lebih komprehensip.

Berdasarkan hasil observasi yang dikakukan pada tanggal 26 Januari 2010 di Kelas V SD Negeri 2 Batuan diketahui guru dalam proses belajar mengajarnya hanya menggunakan metode cermah dan pemberian tugas. Guru dalam mengajarnya langsung menjelaskan definisi-definisi formal sesuai dengan materi yang diajarkannya. Guru sangat dominan dalam proses pembelajaran di kelas. Peran siswa sangat kurang bahkan pasif. Disamping itu dari hasil wawancara dengan guru matematika kelas V SD Negeri 2 Batuan, dikatakan bahwa masih banyak siswa yang lemah dalam menangkap dan menerima pelajaram matematika di kelas. Menurut data yang diperoleh dari guru tersebut bahwa ratarata skor untuk mata pelajaran matematika siswa kelas V SD Negeri 2 Batuan dalam tes sumatif pada semester I tahun 2009 yaitu 6,21. Ini menunjukan bahwa pretasi belajar siswa masih tergolong rendah karena nilai rata-rata masih di bawah standar minimal 6,5. Hal ini diduga disebabkan oleh beberapa faktor diantaranya: (1) guru dalam mengajar masih 
menggunakan metode konvensional yakni ceramah dan ekspositori, sehingga pembelajaran didominasi oleh guru dan sedikit melibatkan siswa, (2) interaksi antara sesama siswa, siswa dengan guru selama proses belajar-mengajar sangat kurang. (3) guru belum mengaitkan materi yang diajarkan di kelas dengan kehidupan nyata siswa selama proses pembelajaran.

Dari uraian yang telah dikemukakan di atas, maka perlu suatu model pembelajaran yang dapat meningkatkan minat dan motivasi belajar siswa serta membuat siswa lebih aktif dalam menyelesaikan masalah matematika dalam kehidupan sehari-hari. Pembelajaran hendaknya juga mengaitkan pengalaman kehidupan nyata siswa dengan materi dan konsep matematika. Salah satu model pembelajaran matematika "yang berorientasi pada matematisasi pengalaman sehari-hari (mathematize everyday experience) dan menerapkan matematika dalam kehidupan sehari-hari (everydaying mathematics) adalah Realistics Mathematics Education (RME).” (Suharta, 2001:2). RME adalah pembelajaran matematika yang mengacu pada konstruktivisme sosial dan dikhususkan pada pendidikan matematika.(Lange dalam Yuwono, 2001:3). Dalam pandangan RME, pengembangan suatu konsep matematika dimulai oleh siswa secara mandiri berupa kegiatan eksplorasi sehingga memberikan peluang pada siswa untuk berkreasi mengembangkan pemikirannya. Pengembangan konsep berawal dari intuisi siswa dan siswa menggunakan strateginya masing-masing dalam memperoleh suatu konsep.

Menurut Hadi (2003:1) RME yang dalam makna Indonesia berarti "Pendidikan Matematika Realistik (PMR) dikembangkan berdasarkan pemikiran Hans Freudenthal yang berpendapat matematika merupakan aktivitas manusia (human activities) dan harus dikaitkan dengan realitas." Ini berarti matematika harus dekat dengan anak dan relevan dengan kehidupan nyata sehari-hari. Matematika sebagai aktivitas manusia berarti manusia harus diberikan kesempatan untuk menemukan kembali ide dan konsep matematika dengan bimbingan orang dewasa. Upaya ini dilakukan melalui penjelajahan berbagai situasi dan persoalan-persoalan sehari-hari. Realistik dalam hal ini dimaksudkan tidak mengacu pada realitas tetapi pada sesuatu yang dapat dibayangkan oleh siswa (Slettenhaar dalam Suharta, 2001:3).

RME yang dipandang suatu konteks nyata sebagai titik tolak belajar matematika mempunyai ciri-ciri sebagai berikut: (1) menggunakan konteks yang nyata sebagai titik awal belajar, (2) menggunakan model sebagai jembatan antara riil dan abstrak, (3) belajar dalam suasana demokratis dan interaktif, (5) menghargai jawaban informal siswa sebelum mereka mencapai bentuk formal matematika.(Nur dalam Suradi, 2001:9)

RME mempunyai konsepsi tentang siswa. Menurut Sutarto (dalam Suradi, 2001:8) 
konsepsi tentang siswa itu meliputi: (1) siswa memiliki seperangkat konsep alternatif tentang ide-ide matematika yang mempengaruhi belajar selanjutnya, (2) siswa memperoleh pengetahuan baru dengan membentuk pengetahuan itu untuk dirinya sendiri, (3) pembentukan pengetahuan merupakan proses perubahan yang meliputi penambahan, kreasi, modifikasi dan penolakan.

Treffers (dalam Suharta, 2001:3) menyebutkan bahwa karakteristik dari RME yaitu : (a) menggunakan dunia nyata. Pembelajaran diawali dengan masalah kontekstual (dunia nyata) sehingga memungkinkan siswa menggunakan pengalaman sebelumnya secara langsung untuk menemukan suatu konsep. Melalui abstraksi dan formalisasi, siswa dapat mengembangkan konsep yang lebih komplit. Kemudian siswa dapat mengaplikasikan konsep-konsep matematika kedalam bidang yang lain ataupun dunia nyata sehingga memperkuat pemahaman konsep. (b) menggunakan model-model. Istilah model berkaitan dengan situasi dan model matematika yang dikembangkan sendiri oleh siswa (self developed models). Peran self developed models merupakan jembatan bagi siswa dari situasi konkret menuju abstrak atau konteks informal ke formal dimana siswa membuat model sendiri dalam menyelesaikan masalah sehingga diperoleh pengetahuan matematika formal ( bersifat abstrak). (c) menggunakan produksi dan konstruksi oleh siswa. Siswa mempunyai kesempatan untuk mengembangkan strategi-strategi informal pemecahan masalah yang dapat mengarah pada konstruksi prosedur-prosedur pemecahan masalah. Dengan bimbingan guru, siswa diharapkan menemukan kembali konsep dalam bentuk formal. (d) menggunakan interaktif. Interaksi antara siswa dan guru merupakan hal mendasar dalam RME. Secara eksplisit bentuk-bentuk interaksi yang berupa negosiasi, penjelasan, pembenaran, setuju, tidak setuju, pertanyaan atau refleksi digunakan untuk mencapai bentuk formal dari bentuk-bentuk informal siswa. (e) keterkaitan unit belajar. Dalam RME, keterkaitan unit-unit matematika adalah esensial. Dengan keterkaitan ini akan memudahkan siswa dalam proses pemecahan masalah.

Ada pendapat menyatakan bahwa model pembelajaran RME "menuntut aktifitas siswa secara optimal. Konsep matematika dipandang sebagai sesuatu yang dapat dikonstruksi oleh siswa, bukan sesuatu bahan yang disampaikan oleh guru secara informatif. Siswa diberi peluang untuk menggali dan membangun konsep secara mandiri." (Sulaiman, 2001:1)

Berkaitan dengan masalah pembelajaran geometri di sekolah dasar yang telah dikemukan di atas, maka model pembelajaran RME diduga sebagai suatu solusi untuk mengatasi permasalahan tersebut. Dalam RME siswa mempelajari konsep-konsep geometri 
berdasarkan kegiatan mereka sehari-hari. Dengan itu diharapkan aktivitas dan pemahaman siswa akan meningkat. Berdasarkan uraian di atas peneliti tertarik untuk mengadakan penelitian yang berjudul "Meningkatkan Aktivitas dan Prestasi Belajar Siswa dalam Pembelajaran Geometri melalui Penerapan Model Pembelajaran RME Pada Siswa Kelas V SD Negeri 2 Batuan Tahun Pelajaran 2009/2010.”

\section{METODE PENELITIAN}

\section{Pendekatan dan Jenis Penelitian}

Penelitian ini menggunakan pendekatan kualitatif, yang memiliki ciri-ciri seperti: (1) latar almiah karena tidak mengubah keadaan kelas, (2) manusia sebagai alat, karena dalam penelitian ini peneliti sendiri atau dengan bantuan orang lain merupakan alat pengumpul data utama, (3) desain bersifat sementara, karena desain yang disusun tidak bersifat kaku dan disesuaikan dengan kenyataan lapangan. Oleh karena penelitian yang akan dilakukan ini memiliki beberapa ciri-ciri yang sama dengan penelitian kualitatif maka penelitian ini menggunakan pendekatan kualitatif.

Jenis penelitian ini adalah penelitian tindakan kelas (classroom action research). Desain atau model PTK yang digunakan dalam penelitian tindakan kelas ini adalah desain PTK model Kurt Lewin yang mengandung empat komponen pada setiap siklus. Keempat komponen tersebut meliputi: (1) perencanaan (planning) yaitu rencana tindakan yang akan dilakukan untuk memperbaiki, meningkatkan atau perubahan perilaku dan sikap sebagai solusinya, (2) tindakan (action) yaitu sesuatu yang dilakukan guru atau peneliti sebagai upaya perbaikan, peningkatan, atau perubahan yang diinginkan, (3) pengamatan (observing) yaitu mengamati hasil atau dampak dari tindakan yang dilaksanakan atau dikenakan kepada siswa, dan (4) refleksi (reflecting) yaitu peneliti mengkaji, melihat dan mempertimbangkan atas hasil atau dampak dari tindakan yang nantinya akan direvisi terhadap rencana sebelumnya.

\section{Tempat dan Subyek Penelitian}

Penelitian ini dilaksanakan di SD Negeri 2 Batuan, dengan subyek penelitian seluruh siswa kelas V Tahun Pelajaran 2009/ 2010 sebanyak 21 orang yang terdiri dari 10 siswa laki-laki dan 11 siswa perempuan. Pelaksanaan penelitian ini dimulai dari tanggal 31 Maret 2010 sampai dengan tanggal 22 April 2010. 


\section{Data dan Sumber Data}

Skor dalam penelitian ini terdiri dari skor aktivitas belajar dan skor prestasi belajar. Kedua skor merupakan data primer, karena masing-masing diperoleh dari pengamatan dan tes secara langsung yang dilakukan peneliti terhadap subjek penelitian.

Catatan lapangan adalah segala hasil pencatatan dari pelaksanaan kegiatan. Catatan lapangan digunakan dalam memperoleh informasi kualitatif yang terkait dengan tindakan yang dilakukan. Catatan lapangan merupakan data primer karena diperoleh dari hasil pencatatan langsung yang dilakukan oleh peneliti dan teman sejawat.

\section{Teknik Pengumpulan Data}

Data yang dikumpulkan dalam penelitian ini meliputi data aktivitas belajar siswa dan data prestasi belajar siswa. Data aktivitas belajar siswa selama mengikuti pembelajaran dikumpulkan dengan teknik observasi. Instrumen yang dipakai dalam pengumpulan data ini adalah menggunakan lembar observasi yang memuat indikator prilaku siswa antara lain: (a) usaha siswa dalam mengaitkan realitas yang digunakan dengan konsep yang dipelajari, (b) interaksi siswa dengan guru pada saat proses pembelajaran berlangsung, (c) interaksi siswa dengan siswa pada saat proses pembelajaran berlangsung, (d) antusiasme siswa dalam proses pembelajaran, (e) partisipasi siswa dalam menyimpulkan materi pelajaran. Lembar observasi dalam penelitian ini terdiri dari 5 indikator, dimana setiap indikator memiliki katagori sebagai berikut: sangat aktif, aktif, cukup aktif, kurang aktif, sangat kurang aktif dengan skor berturut-turut yaitu 4, 3, 2, 1 dan 0. Dengan demikian skor maksimum ideal data aktivitas belajar siswa adalah 20 .

Data prestasi belajar siswa dikumpulkan dengan teknik tes. Instrumen yang dipakai dalam pengumpulan data ini menggunakan tes prestasi belajar yang berupa tes uraian (essay) yang diberikan pada akhir masing-masing siklus.

\section{Teknik Analisis Data}

Data aktivitas belajar siswa dianalisis dengan menggunakan analisis statistik deskriptif, dan digolongkan berdasarkan kriteria dari Nurkancana dan Sunartana (1992:100) . Analisis hasil belajar dilakukan berdasarkan atas rata-rata skor siswa, ketuntasan belajar, dan daya serap (Nurkancana dalam Widianto, 2008:31). Hasil perhitungan rata-rata skor kelas ( M), ketuntasan belajar siswa (KB), dan daya serap (DS) selanjutnya dikomparasikan dengan standar acuan yang ditetapkan Depdikbud, yaitu proses pembelajaran telah optimal, 
jika rata-rata skor kelas $(M) \geq 6,5$, daya serap $(\mathrm{DS}) \geq 65 \%$ dan ketuntasan belajar siswa $(\mathrm{KB}) \geq 85 \%$ (Depdikbud, 1994:34).

\section{Prosedur Penelitian}

Penelitian ini adalah Penelitian Tindakan Kelas (PTK) yang direncanakan dalam 3 (tiga) siklus. Masing-masing siklus terdiri empat komponen, yaitu: (1) perencanaan (planning), (2) tindakan (acting), (3) observasi atau evaluasi (observing) dan (4) refleksi (reflecting).

\section{Refleksi Awal}

Berdasarkan hasil observasi yang dikakukan pada tanggal 26 Januari 2010 di Kelas V SD Negeri 2 Batuan, teridentifikasi masalah yaitu: (1) guru dalam proses belajar mengajarnya hanya menggunakan metode cermah dan pemberian tugas, (2) guru dalam mengajarnya langsung menjelaskan definisi-definisi formal sesuai dengan materi yang diajarkannya, (3) guru sangat dominan dalam proses pembelajaran di kelas, (4) peran siswa sangat kurang bahkan pasif. Disamping itu dari hasil wawancara dengan guru matematika kelas V SD Negeri 2 Batuan, diperoleh informasi yaitu pretasi belajar siswa masih rendah. Hal ini berdasarkan rata-rata skor kelas V SD Negeri 2 Batuan dari tes sumatif pada semester I tahun 2009 yaitu 6,21 .

Berdasarkan situasi tersebut, maka perlu diterapkannya suatu model pembelajaran yang membuat siswa menjadi aktif dan tidak bosan dalam mengikuti pelajaran matematika khususnya pembelajaran bangun datar. Model pembelajaran yang diduga tepat digunakan adalah RME. Dalam RME itu menuntut aktivitas siswa secara optimal. Selain itu, model pembelajaran RME selalu mengaitkan pengalaman siswa sehari-hari di dalam proses pembelajaran. Terlebih lagi pembelajaran bangun datar dan bangun ruang masih bersifat abstrak bagi siswa sekolah dasar. Oleh karena itu dengan model pembelajaran RME yang mengaitkan kehidupan nyata siswa dengan sifat abstrak bangun datar dan bangun ruang, maka proses pembelajaran akan menjadi menarik dan menyenangkan

\section{Siklus 1}

Siklus I dilaksanakan dalam 3 kali pertemuan dengan rincian dua kali pertemuan untuk pelaksanaan tindakan dan satu kali pertemuan untuk melakukan tes prestasi belajar. Pertemuan pertama membahas tentang bangun datar persegi dan persegi panjang. Pertemuan kedua membahas tentang bangun datar segitiga. Siklus I terdiri dari empat komponen meliputi: perencanaan, pelaksanaan, observasi atau evaluasi, dan refleksi. 
Perencanaan Tindakan. Sesuai dengan permasalahan yang muncul pada refleksi awal maka akan diterapkannya model pembelajaran RME dalam pembelajaran bangun datar. Selanjutnya ada beberapa hal yang perlu dipersiapkan dalam siklus ini sebagai berikut: (1) menyusun Rencana Pelaksanaan Pembelajaran (RPP) yang mengacu pada langkah-langkah model pembelajaran RME (2) membuat Lembar Kerja Siswa (LKS), (3) membuat tes prestasi belajar, (4) membuat lembar observasi, (5) membuat buku catatan lapangan.

Pelaksanaan Tindakan. Berdasarkan perencanaan tindakan di atas, pada komponen ini peneliti melaksanakan penerapan model pembelajaran RME dalam pembelajaran bangun datar. Pada pertemuan I, yang akan dibahas adalah bangun datar persegi dan persegi panjang. Adapun yang di bahas meliputi sifat-sifatnya serta cara menghitung luas dan kelilingnya. Adapun langkah-langkah pembelajarannya adalah sebagai berikut:

Tabel 1. Kegiatan guru dan siswa pada pertemuan pertama

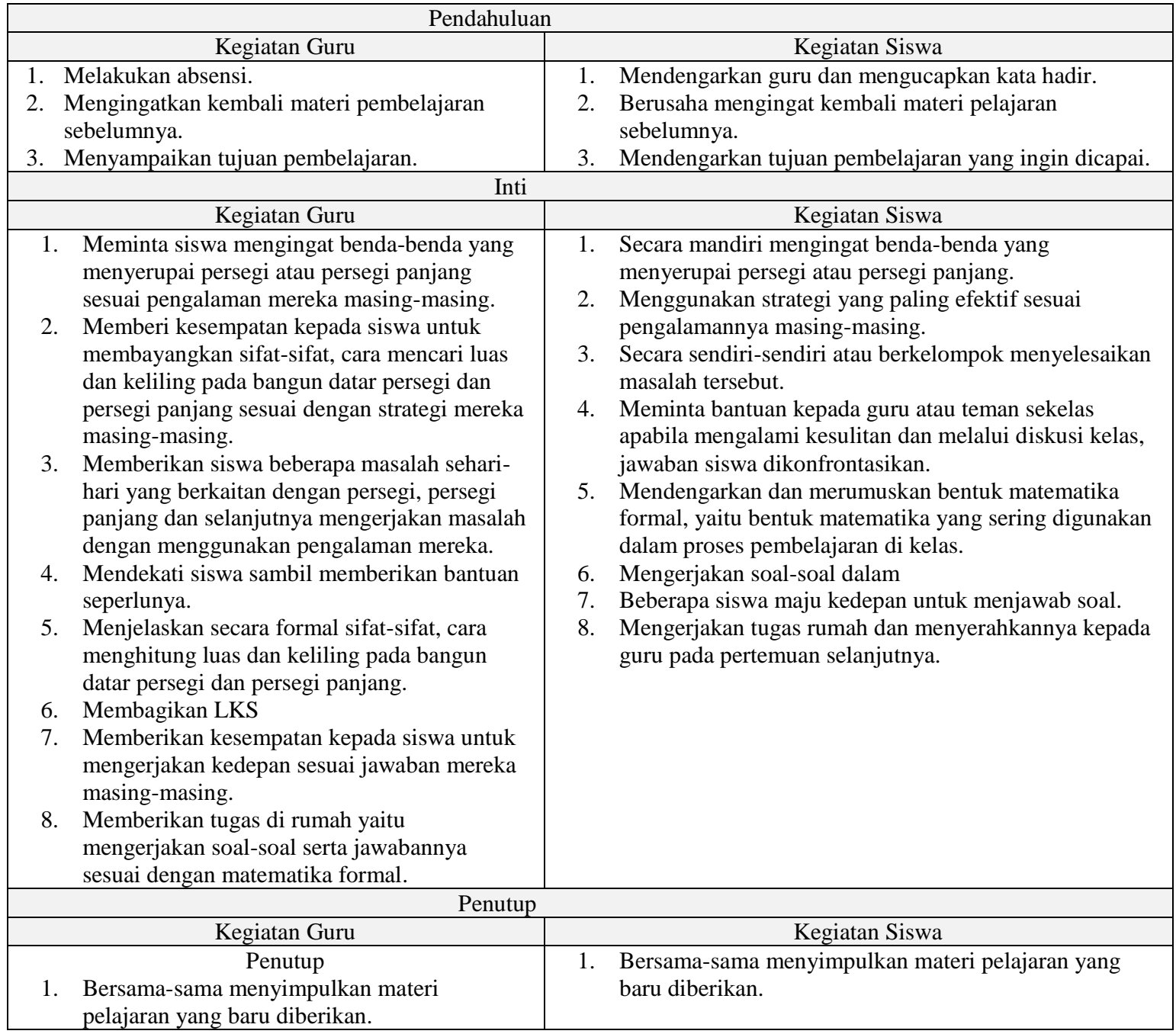


Sedangkan, pada pertemuan kedua materi yang akan dibahas adalah jenis-jenis segitiga, sifat-sifat segitiga serta cara menghitung luas dan keliling segitiga . Adapun langkahlangkah pembelajarannya adalah sebagai berikut:

Tabel 2. Kegiatan guru dan siswa pada pertemuan kedua

\begin{tabular}{|c|c|}
\hline \multicolumn{2}{|c|}{ Pendahuluan } \\
\hline Kegiatan Guru & Kegiatan Siswa \\
\hline $\begin{array}{l}\text { 1. Melakukan absensi. } \\
\text { 2. Mengingatkan kembali materi pembelajaran } \\
\text { sebelumnya. } \\
\text { 3. Menyampaikan tujuan pembelajaran. }\end{array}$ & $\begin{array}{l}\text { 1. Mendengarkan guru dan mengucapkan kata hadir. } \\
\text { 2. Berusa mengingat kembali materi pelajaran sebelumnya. } \\
\text { 3. Mendengarkan tujuan pembelajaran yang ingin dicapai. }\end{array}$ \\
\hline \multicolumn{2}{|l|}{ Inti } \\
\hline Kegiatan Guru & Kegiatan Siswa \\
\hline $\begin{array}{l}\text { 1. Meminta siswa mengingat benda-benda yang } \\
\text { menyerupai segitiga sesuai pengalaman mereka } \\
\text { masing-masing. } \\
\text { 2. } \begin{array}{l}\text { Memberi kesempatan kepada siswa untuk } \\
\text { membayangkan sifat-sifat, cara mencari luas } \\
\text { dan keliling pada bangun datar segitiga sesuai } \\
\text { dengan strategi mereka masing-masing. }\end{array} \\
\text { 3. Memberikan siswa beberapa masalah sehari- } \\
\text { hari yang berkaitan dengan segitiga dan } \\
\text { selanjutnya mengerjakan masalah dengan } \\
\text { menggunakan pengalaman mereka. } \\
\text { 4. Mendekati siswa sambil memberikan bantuan } \\
\text { seperlunya. } \\
\text { 5. Menjelaskan secara formal jenis-jenis, sifat- } \\
\text { sifat, cara menghitung luas dan keliling pada } \\
\text { bangun datar segitiga. } \\
\text { 6. Membagikan LKS } \\
\text { 7. Memberikan kesempatan kepada siswa untuk } \\
\text { mengerjakan kedepan sesuai jawaban mereka } \\
\text { masing-masing. }\end{array}$ & $\begin{array}{l}\text { 1. Secara mandiri mengingat benda-benda yang menyerupai } \\
\text { segitiga } \\
\text { 2. Menggunakan strategi yang paling efektif sesuai } \\
\text { pengalamannya masing-masing. } \\
\text { 3. Secara sendiri-sendiri atau berkelompok menyelesaikan } \\
\text { masalah tersebut. } \\
\text { 4. Meminta bantuan kepada guru atau teman sekelas apabila } \\
\text { mengalami kesulitan dan melalui diskusi kelas, jawaban } \\
\text { siswa dikonfrontasikan. } \\
\text { 5. Mendengarkan dan merumuskan bentuk matematika } \\
\text { formal, yaitu bentuk matematika yang sering digunakan } \\
\text { dalam proses pembelajaran di kelas. } \\
\text { 6. Mengerjakan soal-soal dalam LKS } \\
\text { 7. Beberapa siswa maju kedepan untuk menjawab soal. } \\
\text { 8. Mengerjakan tugas rumah dan menyerahkannya kepada } \\
\text { guru pada pertemuan selanjutnya. }\end{array}$ \\
\hline \multicolumn{2}{|c|}{ Penutup } \\
\hline Kegiatan Guru & Kegiatan Siswa \\
\hline $\begin{array}{l}\text { Bersama-sama menyimpulkan materi } \\
\text { pelajaran yang baru diberikan. }\end{array}$ & $\begin{array}{l}\text { Bersama-sama menyimpulkan materi pelajaran } \\
\text { yang baru diberikan. }\end{array}$ \\
\hline
\end{tabular}

Observasi . Kegiatan observasi dilaksanakan selama proses pembelajaran berlangsung. Observasi terhadap aktivitas belajar siswa dilakukan dengan mengamati prilaku yang tampak menggunakan lembar observasi, sedangkan kegiatan evaluasi dilaksanakan untuk mengetahui prestasi belajar siswa dengan menggunakan tes prestasi belajar pada akhir siklus.

Refleksi. Tahap refleksi dilakukan pada akhir siklus I yang didasarkan pada hasil observasi, evaluasi selama proses pembelajaran dan catatan lapangan. Refleksi ini dilakukan oleh peneliti dengan tujuan untuk mengidentifikasi dampak tindakan pada siklus I, sejauh mana 
hasil yang dicapai, kelemahan serta kendala yang dialami. Permasalahan yang timbul selama pembelajaran siklus I didiskusikan dengan teman sejawat serta guru kelas dan dicari alternatif pemecahannya. Selain itu refleksi dijadikan sebagai masukan untuk menyempurnakan pembelajaran pada siklus II sehingga kelemahan-kelemahan pada siklus I dapat diatasi.

\section{Siklus II}

Siklus II dilaksanakan jika hasil yang diperoleh pada siklus I belum sesuai dengan yang diharapkan. Siklus II dilaksanakan dalam 3 kali pertemuan dengan rincian dua kali pertemuan untuk pelaksanaan tindakan dan satu kali pertemuan untuk melakukan tes prestasi belajar. Pertemuan pertama membahas tentang bangun datar trapesium. Pertemuan kedua membahas tentang bangun datar jajar genjang dan belah ketupat. Adapun langkahlangkahnya yang diambil serupa dengan siklus I yaitu, perencanaan tindakan, pelaksanaan tindakan, observasi atau evaluasi dan refleksi. Namun demikian langkah-langkahnya merupakan penyempurnaan dari langkah-langkah pada siklus I.

Perencanaan Tindakan. Dalam perencanaan pada diklus II ini peneliti menyiapkan hal-hal yang hampir sama pada siklus I yaitu: (1) menyusun Rencana Pelaksanaan Pembelajaran (RPP) yang mengacu pada langkah-langkah model pembelajaran RME, (2) membuat Lembar Kerja Siswa (LKS), (3) membuat tes prestasi belajar, (4) membuat lembar observasi, (5) membuat buku catatan lapangan.

Pelaksanaan Tindakan. Berdasarkan perencanaan tindakan di atas, pada komponen ini peneliti melaksanakan penerapan model pembelajaran RME dalam pembelajaran bangun datar. Pada pertemuan pertama materi yang akan dibahas adalah jenis-jenis, sifat-sifat dan cara menghitung luas trapesium, sedangkan pada pertemuan kedua materi yang akan dibahas adalah sifat-sifat serta cara menghitung luas jajar genjang dan belah ketupat . Adapun langkah-langkah pembelajarannya adalah sebagai berikut:

Observasi. Kegiatan observasi dilaksanakan selama proses pembelajaran berlangsung. Observasi terhadap aktivitas belajar siswa dilakukan dengan mengamati prilaku yang tampak menggunakan lembar observasi, sedangkan kegiatan evaluasi dilaksanakan untuk mengetahui prestasi belajar siswa dengan menggunakan tes prestasi belajar pada akhir siklus.

Refleksi. Seperti pada siklus I, pada siklus II ini kembali dilakukan refleksi berdasarkan hasil observasi dan hasil tes prestasi belajar siswa yang diperoleh pada akhir siklus II. 
Refleksi ini dilakukan oleh peneliti dengan tujuan untuk mengidentifikasi hasil tindakan pada siklus II, sejauh mana hasil yang dicapai, kelemahan serta kendala yang dialami. Permasalahan yang timbul selama pembelajaran siklus II didiskusikan dengan teman sejawat serta guru kelas dan dicari alternatif pemecahannya. Selain itu refleksi dijadikan sebagai masukan untuk menyempurnakan pembelajaran pada siklus III sehingga kelemahan-kelemahan pada siklus II dapat diatasi.

\section{Siklus III}

Siklus III dilaksanakan jika hasil yang diperoleh pada siklus II belum sesuai dengan yang diharapkan. Siklus III dilaksanakan dalam 3 kali pertemuan dengan rincian dua kali pertemuan untuk pelaksanaan tindakan dan satu kali pertemuan untuk melakukan tes prestasi belajar. Pertemuan pertama membahas tentang bangun datar layang-layang. Pertemuan kedua membahas tentang bangun datar lingkaran. Adapun langkah-langkahnya yang diambil serupa dengan siklus II yaitu, perencanaan tindakan, pelaksanaan tindakan, observasi atau evaluasi dan refleksi. Namun demikian langkah-langkahnya merupakan penyempurnaan dari langkah-langkah pada siklus II.

Perencanaan Tindakan. Dalam perencanaan pada diklus III ini peneliti menyiapkan halhal yang hampir sama pada siklus II yaitu: (1) menyusun Rencana Pelaksanaan Pembelajaran (RPP) yang mengacu pada langkah-langkah model pembelajaran RME, (2) membuat Lembar Kerja Siswa (LKS), (3) membuat tes prestasi belajar, (4) membuat lembar observasi, (5) membuat buku catatan lapangan.

Pelaksanaan Tindakan. Berdasarkan perencanaan tindakan di atas, pada komponen ini peneliti melaksanakan penerapan model pembelajaran RME dalam pembelajaran bangun datar, yang membahas sifat-sifat, cara menghitung luas dan keliling layang-layang. Pada pertemuan pertama materi yang akan dibahas adalah sifat-sifat, cara menghitung luas dan keliling lingkaran Adapun langkah-langkah pembelajarannya adalah sebagai berikut: Observasi. Kegiatan observasi dilaksanakan selama proses pembelajaran berlangsung. Observasi terhadap aktivitas belajar siswa dilakukan dengan mengamati prilaku yang tampak menggunakan lembar observasi, sedangkan kegiatan evaluasi dilaksanakan untuk mengetahui prestasi belajar siswa dengan menggunakan tes prestasi belajar pada akhir siklus. 
Refleksi dilakukan berdasarkan hasil observasi dan hasil tes prestasi belajar yang dilaksanakan pada akhir siklus III. Hasil refleksi pada siklus III digunakan sebagai dasar untuk merumuskan kesimpulan terhadap hasil penelitian serta saran-saran demi penyempurnaan penelitian ini.

\section{Pengecekan Keabsahan Data}

Untuk mengecek keabsahan data digunakan teknik triangulasi, pemeriksaan sejawat dengan guru serta melalui diskusi dengan dosen pembimbing. Menurut Moleong (2004:178) "triangulasi adalah teknik pemeriksaan keabsahan data yang memanfatkan sesuatu yang lain di luar data itu untuk keperluan pengecekan atau sebagai pembanding terhadap data itu." Teknik pemeriksaan sejawat melalui diskusi dilakukan dengan cara mengekspos hasil sementara atau hasil akhir yang diperoleh dalam bentuk diskusi analitik dengan rekan-rekan sejawat.

Dalam penelitian ini triangulasi dan pemeriksaan sejawat dilakukan melalui diskusi secara terpadu, yang melibatkan dua orang teman sejawat dan seorang guru. Hasil triangulasi dan teman sejawat tersebut dikonsultasikan pada dosen pembimbing, untuk mendapatkan arahan dan revisi bila diperlukan dalam upaya mendapatkan data dengan derajat kepercayaan yang diharapkan.

\section{HASIL PENELITIAN DAN PEMBAHASAN}

\section{Hasil Penelitian}

Berdasarkan hasil analisis data diperoleh skor dan katagori aktivitas belajar siswa dalam Tabel 2.

Tabel 2. Hasil Analisis Data Aktivitas Belajar Siswa

\begin{tabular}{|c|c|c|}
\hline Siklus & Rata-Rata Skor Aktivitas & Kategori \\
\hline Prasiklus & 7,19 & Kurang Aktif \\
\hline I & 8,74 & Cukup Aktif \\
\hline II & 10,38 & Cukup Aktif \\
\hline III & 12,17 & Aktif \\
\hline
\end{tabular}


Sementara berdasarkan hasil analisis data aktivitas belajar siswa diperoleh persentase peningkatan aktivitas belajar siswa dari prasiklus ke siklus I, siklus I ke siklus II dan siklus II ke siklus III berturut-turut sebesar 21,56\%, 18,76\% dan 17,24\%.

Berdasarkan hasil perhitungan rata-rata skor prestasi belajar siswa (M), daya serap (DS), dan ketuntasan belajar ( $\mathrm{KB}$, maka dapat disajikan hasil pengolahan data mengenai prestasi belajar siswa dan persentase peningkatan rata-rata skor prestasi belajar siswa (M), daya serap (DS), dan ketuntasan belajar (KB) pada Tabel 3, dan Tabel 4..

Tabel 3. Hasil Analisis Data Prestasi Belajar Siswa

\begin{tabular}{|c|c|c|c|}
\hline \multirow{2}{*}{ Siklus } & \multicolumn{3}{|c|}{ Prestasi Belajar } \\
\cline { 2 - 4 } & $\begin{array}{c}\text { Rata-rata skor } \\
\text { kelas (M) }\end{array}$ & $\begin{array}{c}\text { Daya Serap } \\
\text { (DS) }\end{array}$ & Ketuntasan Belajar (KB) \\
\hline $\begin{array}{c}\text { Prasiklu } \\
\text { s }\end{array}$ & 2,00 & $20,00 \%$ & $0,00 \%$ \\
\hline I & 6,35 & $63,45 \%$ & $52,38 \%$ \\
\hline II & 6,95 & $69,50 \%$ & $65,00 \%$ \\
\hline III & 7,28 & $72,75 \%$ & $90,00 \%$ \\
\hline
\end{tabular}

Tabel 4 Presentase Peningkatan Prestasi Belajar Siswa

\begin{tabular}{|c|c|c|c|}
\hline $\begin{array}{c}\text { Wakt } \\
\mathbf{u} \\
\begin{array}{c}\text { Pelak } \\
\text { sanaa } \\
\mathbf{n}\end{array}\end{array}$ & $\begin{array}{c}\text { Rata-rata skor } \\
\text { kelas (M) }\end{array}$ & Deningkatan Prestasi Belajar \\
\hline Pra-I & $217,50 \%$ & $217,25 \%$ & Ketuntasan Belajar (KB) \\
\hline I-II & $9,45 \%$ & $9,54 \%$ & Tidak terdefinisi \\
\hline II-III & $4,75 \%$ & $4,68 \%$ & $24,09 \%$ \\
\hline
\end{tabular}

\section{Pembahasan}

Dalam penelitian ini, sebelum pelaksanaan tindakan terlebih dahulu dilakukan prasiklus. Prasiklus adalah suatu kegiatan pembelajaran dimana kegiatan ini dilakukan sebelum pelaksanaan tindakan. Dalam PTK ini, prasiklus dilakukan sebanyak 2 kali meliputi: (1) observasi awal, dan (2) pemberian tes prasiklus. Kedua langkah tersebut dilakukan untuk mengetahui aktivitas belajar awal siswa dan kemampuan belajar awal siswa sebelum pelaksanaan tindakan.

Berdasarkan hasil analisis data yang diperoleh dari hasil observasi awal dan tes prasiklus di dapat informasi tentang aktivitas dan prestasi belajar siswa khususnya pada pelajaran matematika belum mencapai hasil yang optimal. Hal ini dapat dilihat dari skor aktivitas 
belajar siswa yaitu 7,19 dengan kategori "kurang aktif". Selain itu prestasi belajar siswa dilihat dari rata-rata skor kelas $(\mathrm{M})$ pada prasiklus adalah 2,00, daya serap (DS) $=20,00 \%$, dan ketuntasan belajar $(\mathrm{KB})=0,00 \%$. Kedua hal ini menunjukkan bahwa aktivitas belajar siswa dalam mengikuti proses pembelajaran dan prestasi belajar siswa dalam pelajaran matematika khusunya bangun datar masih rendah. Berdasarkan hal tersebut maka peneliti melakukan PTK dengan menerapkan model pembelajaran RME sebagai salah satu upaya untuk memperbaiki praktek pembelajaran di kelas tersebut.

Hasil analisis data aktivitas belajar siswa diketahui bahwa rata-rata skor aktivitas belajar siswa pada siklus I yaitu 8,74 dengan kategori "cukup aktif”. Jika dibandingkan dengan hasil observasi awal maka persentase peningkatan skor aktivitas belajar siswa sebesar 21,56\%. Dari hasil analisis data prestasi belajar siswa pada siklus I diperoleh bahwa ratarata skor kelas $(M)=6,35$, daya serap $(\mathrm{DS})=63,45 \%$, dan ketuntasan belajar $(\mathrm{KB})=$ $52,38 \%$. Jika dibandingkan dengan hasil prasiklus yang diperoleh dari tes awal maka persentase peningkatan rata-rata skor kelas (M) sebesar 217,50\%, daya serap (DS) sebesar $217,25 \%$, dan ketuntasan belajar (KB) tidak terdefinisi. Persentase peningkatan ketuntasan belajar (KB) dikatakan tidak terdefinisi, itu merujuk pada lampiran 35. Pada lampiran 35, persentase peningkatan ketuntasan belajar (KB) dari prasiklus ke siklus I dihitung menggunakan rumus:

$$
\frac{K B_{\text {siklusI }}-K B_{\text {prasiklus }}}{K B_{\text {prasiklus }}} \times 100 \%
$$

Keterangan:

$$
\begin{aligned}
& \mathrm{KB}_{\text {siklus I }}=\text { Ketuntasan Belajar Siklus I } \\
& \mathrm{KB}_{\text {prasiklus }}=\text { Ketuntasan Belajar Prasiklus }
\end{aligned}
$$

karena $\mathrm{KB}_{\text {prasiklus }}$ sebesar $0,00 \%$ (penyebut $=0$ ), maka persentase peningkatan ketuntasan belajar (KB) dari prasiklus ke siklus I tidak terdefinisi. Namun peningkatan ketuntasan belajar dari prasiklus ke siklus I sebesar 52,38\%. Walaupun telah terjadi peningkatan aktivitas dan prestasi belajar siswa dari prasiklus ke siklus I, namun pembelajaran belum mencapai kriteria keberhasilan minimal yaitu minimal aktivitas belajar dengan kategori “aktif", $\mathrm{M}=6,5, \mathrm{DS}=65 \%$ dan $\mathrm{KB}=85 \%$.

Karena hasil pelaksanaan tindakan pada siklus I belum memenuhi kriteria keberhasilan minimal, maka peneliti bersama teman sejawat melakukan refleksi terhadap pelaksanaan tindakan pada siklus I untuk mendiskusikan faktor-faktor yang diduga menyebabkan kurang berhasilnya pembelajaran yang telah dilaksanakan. Dari hasil refleksi dan catatan lapangan ( lampiran 15 ) diperoleh bahwa kurang berhasilnya pembelajaran 
pada siklus I disebabkan oleh 2 faktor yaitu: (1) faktor yang berasal dari siswa dan (2) faktor yang berasal dari peneliti sebagai guru. Faktor yang berasal dari siswa antara lain: (1) siswa belum terbiasa dengan model pembelajaran RME, (2) siswa terlihat pasif, karena hanya memperhatikan penjelasan dan peragaan yang dilakukan guru sehingga terkesan guru yang menjadi pusat pembelajaran, (3) ada beberapa siswa yang bermain pada saat guru menjelaskan materi. Sedangkan faktor yang berasal dari peneliti sebagai guru antara lain: (1) guru terlalu cepat dalam menjelaskan materi, (2) pendekatan guru kepada siswa pada saat siswa mengerjakan LKS masih kurang intensif, dan (3) guru kurang senyum dan ramah, sehingga siswa kelihatan takut dan tegang dalam mengikuti proses pembelajaran.

Berdasarkan hasil refleksi, maka perlu dilakukan penyempurnaan pelaksanaan tindakan pada siklus II, yaitu (1) memberitahu siswa langkah-langkah model pembelajaran RME, (2) ikut melibatkan beberapa siswa dalam peragaan yang dilakukan guru agar siswa dapat memahami materi yang diajarkan oleh guru, dan (3) menegur secara langsung siswa yang bermain pada saat guru menjelaskan materi agar tidak mengulanginya lagi, (4) dalam menjelaskan materi, guru sedikit memperlambat intonasi suara agar siswa bisa mengikutinya, (5) guru agar lebih sering memberikan bantuan kepada siswa saat menjawab LKS, dan (6) guru sekali-sekali membuat hal-hal yang bersifat lucu dalam proses pembelajaran agar siswa tidak merasa tegang dalam mengikuti proses pembelajaran.

Pada siklus II dari hasil analisis data aktivitas belajar siswa diketahui bahwa rata-rata skor aktivitas belajar siswa yaitu 10,38 dengan kategori “cukup aktif”. Jika dibandingkan dengan hasil analisis data aktivitas belajar siswa pada siklus I, nampak terjadi peningkatan dengan persentase peningkatan skor aktivitas belajar siswa dari siklus I ke siklus II sebesar 18,76\%. Walaupun telah terjadi peningkatan skor aktivitas belajar siawa, namun aktivitas belajar siswa pada siklus II masih dalam kategori “cukup aktif”. Dari hasil analisis data prestasi belajar siswa diperoleh bahwa rata-rata skor kelas $(\mathrm{M})=6,95$, daya serap $(\mathrm{DS})=69,50 \%$, dan ketuntasan belajar $(\mathrm{KB})=65,00 \%$. Jika dibandingkan dengan hasil analisis data prestasi belajar siswa pada siklus I, juga nampak terjadi peningkatan dengan persentase peningkatan rata-rata skor kelas (M) sebesar 9,45\%, daya serap (DS) sebesar 9,54\%, dan ketuntasan belajar (KB) sebesar 24,09\%. Walaupun rata-rata skor kelas (M) dan daya serap (DS) telah memenuhi kriteria yang ditetapkan yaitu tercapainya minimal rata-rata skor kelas 6,5 dan daya serap 65,00\% akan tetapi jika dilihat dari aktivitas belajar siswa dan pencapaian ketuntasan belajar siswa belum memenuhi kriteria minimal yang diharapkan. Hal ini dapat dilihat dari aktivitas belajar siswa yang baru mencapai kategori "cukup aktif” dari kategori 
“aktif” yang diharapkan. Selain itu pencapaian ketuntasan belajar siswa yang baru mencapai “65,00\%” dari 85,00\% yang diharapkan.

Karena hasil pelaksanaan tindakan pada siklus II juga belum memenuhi kriteria keberhasilan, peneliti bersama teman sejawat kembali melakukan refleksi terhadap pelaksanaan tindakan pada siklus II untuk mendiskusikan faktor-faktor yang menyebabkan kurang berhasilnya pembelajaran yang dilaksanakan. Berdasarkan hasil refleksi dan catatan lapangan (lampiran 23), disimpulkan yang menyebabkan kurang berhasilnya pembelajaran pada siklus II antara lain: (1) siswa yang kemampuanya masih rendah, masih malu bertanya kepada teman dan guru, (2) siswa belum mampu mengaitkan materi pelajaran dengan benda-benda yang ada dalam lingkungan sekitarnya, (3) dalam menjawab pertanyaan guru maupun dalam pembahasan masih didominasi oleh siswa yang pandai, dan siswa yang memiliki kemampuan rendah cenderung pasif, (4) guru dalam memberikan bantuan kepada siswa dalam mengerjakan LKS tidak merata, (5) guru kurang memberi kesempatan kepada siswa yang kemampuannya masih rendah untuk mencoba menjawab soal ke depan kelas, (6) guru jarang memberikan apresiasi dan pujian kepada siswa yang menjawab soal dengan benar, dan (7) guru masih kurang tegas dalam memberikan teguran kepada siswa yang bermain saat mengikuti proses pembelajaran.

Untuk mengatasi faktor-faktor tersebut, hal-hal yang dilaksanakan adalah sebagai berikut: (1) memotivasi siswa agar tidak malu bertanya jika belum mengerti terhadap materi yang disampaikan, (2) guru memberikan lebih banyak contoh soal yang berkaitan dengan kehidupan sehari-hari, (3) memberi kesempatan kepada siswa yang kemampuanya kurang untuk menulis jawaban yang telah dibuat di LKS ke papan tulis, dan (4) memberikan apresiasi dan pujian kepada siswa yang menjawab soal dengan benar.

Dari penyempurnaan pelaksanaan tindakan pada siklus II telah menunjukkan adanya peningkatan dalam pelaksanaan tindakan siklus III, diantaranya: (1) siswa sudah berani bertanya baik pada teman maupun kepada guru jika mereka belum paham terhadap materi yang dijelaskan oleh guru, (2) siswa sudah mampu mengaitkan materi pelajaran dengan benda-benda yang ada dalam lingkungan disekitarnya, dan (4) aktivitas siswa secara klasikal dalam mengikuti proses pembelajaran di kelas sudah aktif.

Pada siklus III dari hasil analisis data aktivitas belajar siswa diperoleh bahwa rata-rata skor aktivitas belajar siswa yaitu 12,17 dengan kategori “aktif”. Jika dibandingkan dengan hasil analisis data aktivitas belajar pada siklus II, nampak telah terjadi peningkatan dengan persentase peningkatan skor aktivitas belajar siswa dari siklus II ke siklus III sebesar $17,24 \%$. Dari hasil analisis data prestasi belajar siswa diperoleh bahwa rata-rata skor kelas 
$(\mathrm{M})=7,28$, daya serap $(\mathrm{DS})=72,75 \%$, dan ketuntasan belajar $(\mathrm{KB})=90,00 \%$. Jika dibandingkan dengan hasil analisis data prestasi belajar pada siklus II juga nampak terjadi peningkatan dengan persentase peningkatan rata-rata skor kelas (M) sebesar 4,75\%, daya serap (DS) sebesar 4,68\%, dan ketuntasan belajar (KB) sebesar 38,46\%.

Mengacu pada bab III bahwa pembelajaran dikatakan optimal apabila aktivitas belajar siswa telah mencapai minimal kategori "aktif", rata-rata skor kelas $(\mathrm{M}) \geq 6,5$, ketuntasan belajar $(\mathrm{KB}) \geq 85,00 \%$ dan daya serap $(\mathrm{DS}) \geq 65,00 \%$. Dari hasil analisis data yang diperoleh pada siklus III, maka pembelajaran pada siklus III telah optimal karena memenuhi kriteria pembelajaran minimal yang telah ditetapkan. Oleh karena pembelajaran telah optimal maka penelitian ini dihentikan sampai pada siklus III.

Dari uraian di atas, penelitian ini dapat dikatakan berhasil karena aktivitas dan prestasi belajar siswa kelas V SD Negeri 2 Batuan telah mengalami peningkatan dimana aktivitas belajar siswa telah tergolong aktif dan prestasi belajar siswa telah mencapai kriteria minimal yang ditetapkan. Hal ini mengindikasikan bahwa dengan penerapan model pembelajaran RME pada pembelajaran bangun datar terjadi peningkatan aktivitas dan prestasi belajar siswa.

\section{PENUTUP}

\section{Simpulan}

Berdasarkan hasil analisis data dan pembahasan hasil penelitian, maka dapat ditarik kesimpulan sebagai berikut.

1. Dengan penerapan model pembelajaran RME terjadi peningkatan aktivitas belajar siswa kelas V SD Negeri 2 Batuan tahun pelajaran 2009/2010 pada pembelajaran geometri khususnya bangun datar. Hal ini ditunjukkan dengan persentase peningkatan skor aktivitas belajar siswa dari prasiklus ke siklus I sebesar 21,56\%, siklus I ke siklus II sebesar $18,76 \%$ dan siklus II ke siklus III sebesar 17,24\%.

2. Dengan penerapan model pembelajaran RME terjadi peningkatan prestasi belajar siswa kelas V SD Negeri 2 Batuan tahun pelajaran 2009/2010 pada pembelajaran geometri khususnya bangun datar. Hal ini ditunjukkan dengan persentase peningkatan skor ratarata kelas (M) dari prasiklus ke siklus I sebesar 217,50\%, siklus I ke siklus II sebesar 9,45\%, siklus II ke III sebesar 4,75\%. Persentase peningkatan daya serap (DS) dari prasiklus ke siklus I sebesar 217,25\%, siklus I ke siklus II sebesar 9,54\%, siklus II ke siklus III sebesar 4,68\%. Persentase peningkatan ketuntasan belajar (KB) dari prasiklus 
ke siklus I tidak terdefinisikan, siklus I ke siklus II sebesar 24,09\%, siklus II ke siklus III sebesar $38,46 \%$.

\section{Saran}

Adapun saran-saran yang diberikan sehubungan dengan simpulan di atas adalah sebagai berikut.

1. Bagi guru-guru SD disarankan untuk menjadikan model pembelajaran RME sebagai salah satu alternatif dalam pemilihan model pembelajaran di SD karena terbukti terjadi peningkatan aktivitas dan prestasi belajar siswa.

2. Kepada peneliti lain, diharapkan untuk senantiasa melakukan penelitian lebih lanjut dalam pembelajaran matematika baik di sekolah yang berbeda atau pada pokok bahasan yang berbeda sehingga aktivitas dan prestasi belajar siswa dapat terus ditingkatkan.

\section{DAFTAR PUSTAKA}

Abdurrahman, Mulyono. 2003. Pendidikan Bagi Anak Berkesulitan Belajar. Jakarta: Rineka Cipta

Anwar, Desi. 2001. Kamus Lengkap Bahasa Indonesia. Surabaya: PT Karya Aditama

Arthawan, I Kadek. 2004. Penerapan Teknik Permainan Matematika dalam Pembelajaran Bilangan Bulat sebagai Upaya Meningkatkan Aktivitas dan Prestasi Belajar Matematika Siswa Kelas V SD Negeri 1 Sinabun Tahun Pelajaran 2003/2004. Skripsi. (Tidak Diterbitkan). Singaraja: STKIP Singaraja

Aunurrahman. 2009. Belajar dan Pembelajaran. Bandung: Alfabeta

Badudu, J.S. 2001. Kamus Umum Bahasa Indonesi. Jakarta: Pustaka Sinar Harapan

Depdikbud. 1994. Petunjuk Pelaksanaan Proses Belajar Mengajar. Jakarta: Depdikbud.

Djuwairiyah, Siti. 2007. Penerapan Metode Belajar Aktif Sebagai Upaya MembantuMeningkatkan Prestasi Belajar Pada Siswa Kelas 6, (Online), (http://www.intanpariwara.co.id/penyusunan_ktsp.pdf, diakses 18 Pebruari 2010)

Fathani, Abdul Halim. 2009. Matematika Hakikat \& Logika. Yogyakarta: Ar-Ruzz Media

Hadi, Sutarto. 2003. PMR: Menjadikan Pelajaran Matematika Lebih Bermakna Bagi Siswa, (Online), (www.pmri.or.id/download/paper/2s hadi pmri.doc, diakses 4 Januari 2010)

Hasyim, Hadi Muttaqin. 2009. Tujuan Pembelajaran Matematika, (Online), (http://muttaqinhasyim.wordpress.com/2009/06/14/tujuan-pembelajaran-matematika/, diakses 16 Pebruari 2010)

Isjoni. 2010. Cooperative Learning. Bandung: Alfabeta

Johar, Rahmah. 2001. Konstruktivisme atau Realistik? Makalah disajikan dalam Seminar

Nasional Realistic Mathematics Education (RME), FMIPA UNESA, Surabaya, 24 Februari. 
